\title{
明治宮殿の設計内容に見る儀礼空間の意匠的特徵 THE CHARACTERISTICS IN THE DESIGN MEANINGS OF THE MEIJI PALACE'S CEREMONIAL SECTION
}

\author{
山崎 鯛介* \\ Taisuke YAMAZAKI
}

\begin{abstract}
This paper shows that in the ceremonial section of the Meiji Palace, the grandiose interior was designed in relation to its use. The public part of the Meiji Palace was clearly divided into the ceremonial section and the daily-work section by means of building planning and interior design. In the ceremonial section, the ornaments were designed selecting the motifs and the colours to show the image of each ceremony (the audience and the party). The patterns of ornaments were derived from the ancient tresures in Japan, and the most of the ornaments were manufactured applying modern techniques.
\end{abstract}

Keywords : Meiji Palace, Modern Japanese-style, interior design 明治宮殿、近代和風、室内意匠

\section{1. 緒言}

近代の宮殿として建設された明治宮殿（正式には「宮城」）の意匠 的特徴については、これまで『明治工業史 建築篇』(工学会、昭和

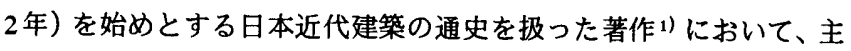
に謁見所や㗽宴所などの建物が取り上げられ、その内部空間に見られ る立式对応、大空間、和洋折哀といった特幑が写真とともに紹介され てきた。また、宮内庁所蔵史料を用いた小野木重勝博士の研究論文 『近代和風宮廷建築における和洋折表技法に関する研究』(昭和 62 年 度科学研究費補助金 [一般研究C] 研究成果報告書) では、宮殿全体 の建物を対象にそこで用いられた意匠や技法の特徵が詳細に検討さ れ、その結果、奥宮殿には緁毯や暖炉などの洋風要素が見られるもの の全体的には伝統的な意匠・技法が用いられたのに対し、表宮殿には それらとともに室内装飾や構造技術にも洋風要素が積極的に導入され ていたことが明らかにされた2)。このように、明治宮殿の意匠的特徵 については、これまで「表宮殿」と「奥宮殿」とを対比的に捉える図 式の中で多くのことが明らかにされてきたといえる。

しかし、明治以降の天皇には、古代以来の皇位を継承する伝統的な 存在であることと共に、西洋諸国をモデルに近代化を推進する近代国 家の君主としての役割も求められたため、表宮殿における活動には国 家政務の裁可や外国公使の謁見、皇室外交を目的とした宮中儀礼な
ど、それまでとは異なる新しい内容が取り入れられ、それはまた、天 皇のそうした多様な活動の場となる明治宮殿にどのような建築的形式 を与えるべきか、また「伝統的」でありながら「近代的」でもある天 皇の二面性にどのような意匠表現を与えるべきかといった問題とし て、宮殿の設計内容にも深く関わってきたと考えられる。こうした 「近代の宮殿」に求められた複雑な要求が竣エした明治宮殿の設計内 容にどのような形で示されたか具体的に理解しようとするとき、表宮 殿の設計経緯や設計内容については、まだ充分に明らかにされていな い点が多く、また従来の「表宮殿」と「奥宮殿」を対比的に捉える図 式では、建物の具体的な特幑が把握しきれないと考えられる。

そうした認識から、拙稿「明治宮殿の建設経絔に見る表宮殿の設計 経緯」(『日本建築学会計画系論文集』、第 572 号、pp.159〜 166)で は、表宮殿の特徴として知られる大空間・和洋折表の内部空間につい て、まずその成立過程を解明することを目的とし、既往研究でほとん ど取り上げられることのなかった明治 16 年 7 月以降の建設経緯につ いて、明治宮殿の竣工記録である『皇居御造営誌』(内匠寮、明治 25 年）に加え、皇居造営に関する公文書である『皇居造営録』（皇居御 造営事務局、明治 9 年 23 年) p東京都立中央図書館木子文庫所収 の明治宮殿関係史料などを用いて、工事過程で加えられた設計変更の 内容について詳細に検討した。その結果、表宮殿の特徴として知られ

* 東京工業大学大学院理工学研究科 助手 $\cdot$ 工修

Research Assistant, Dept. of Architecture, Graduate School of Science and Engineering, Tokyo Institute of Technology, M. Eng. 
る大空間・和洋折衷の内部空間は着工当初には決定しておらず、工事 と並行して行われた設計変更の際に決められたことを明らかにし、ま た壁面に用いられた洋風意匠については、西洋風の宮中夜会を想定し て導入された可能性が高いことを家具計画書の内容から明らかにし た。そして、設計変更の時期と宮内卿として皇居造営事業に強い権限 を持っていた伊藤博文の就任期間がほぼ一致することや、装飾化・洋 風化を意図した設計変更の内容と西洋風の宮中夜会の開催を重視した 伊藤の宮中政策とが一致することから、こうした表宮殿の壮麗化に は、条約改正問題を背景に皇室外交を推進した伊藤博文ら新政府の意 向が強く働いていた可能性が高いことを論じた。

つづく本研究では、同じく明治宮殿の表宮殿に見られる壮麗な内部 空間について取り上げ、その竣工時の意匠を詳細に検討するとともに それらを表宮殿全体の平面計画と併せて検討することで、そうした意 匠的特幑が「近代の宮殿」に対する複雑な要求とどのように関係ゔけ られ、また何を表現したものであったかについて考察した。従来の研 究では平面計画についての検討が不足していたため、明治宮殿の特徴 は謁見所や饗宴所など建築単体の特徵として論じられるに留まること が多かったが、本研究では平面計画を重視することによって、まず 「宮殿」としての全体構成を理解し、その上に個々の建物の意匠的特 徴を位置づけ直すことを試みた。

既往研究には、表宮殿の意匠的特徵について、それを宮殿の全体計 画の中に位置ゔけて理解しようとしたものは見られない。宮殿全体を 扱った小野木重勝『近代和風宮廷建築における和洋折哀技法に関する 研究』(先揭) においても、建物の室内意匠については表宮殿と奥宮 殿の比較に留まり、それそれの建物の具体的特徴が全体計画の中でど のように位置づけられたかについては、あまり触れられていない。

史料として、明治宮殿の竣工時の様子については、宮内庁書陵部所 蔵の『皇居御造営誌』(先揭) および『皇居御造営内部諸装飾明細図』 （内匠寮、明治 25 年）を用いて明らかにした。また、建設過程の設計 内容については、皇居造営の公文書である『皇居造営録』(先揭)や 東京都立中央図書館木子文庫所収の明治宮殿関係史料などを用いて明

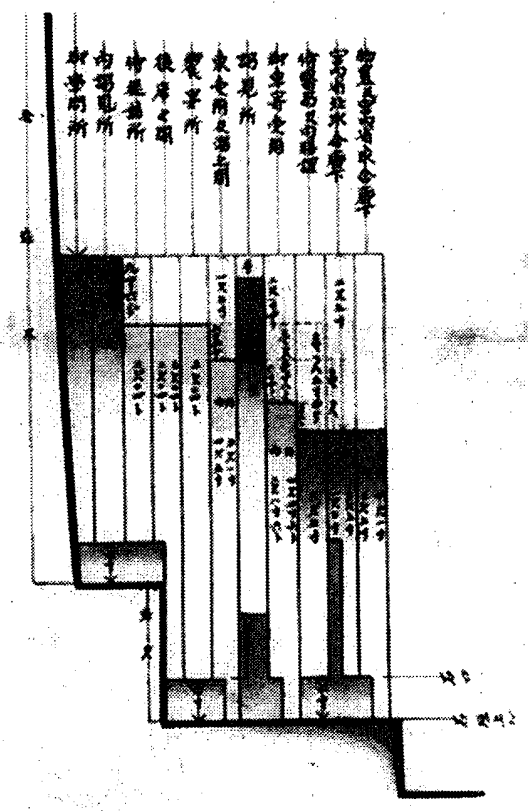

らかにした。なお、明治 宮殿の各建物の名称に ついては、竣工後の明 治 21 年 12 月 27 日に正 式名称が宮内省から布 達され、たとえば造営 中に「謁見所」と呼ばれ ていた建物は「正殿」 へ、「御学問所」と呼ば れていた部屋は「表御 座所」へと改称された が、本研究では、設計過 程の設計図書や公文書 を扱う関係上、建物の 名称には「謁見所」など 造営中の名称を用いる こととした。
2. 表宮殿の平面計画・意匠計画に見られるゾーニング

天皇の公務の場である表宮殿には、日常政務を執る場所と宮中儀礼 を行う場所の両方が必要とされたが、それぞれの施設では必要とされ る規模も使用頻度も異なることから、これらを適切にゾーニングする ことは平面計画上の重要な課題であったと考えられる。本章では、宮 殿全体の配置計画が高低差のある西之丸・山里の敷地においてどのよ うに行われたかをまず明らかにし、その上で表宮殿に見られるこれら 2 種類の用途がどのようにソーニングされたかについて論じた。

明治宮殿が建設された西之丸と山里の境界部分について、『皇居御 造営誌』には、「山里卜旧西丸ノ地形高低凡二十余尺二及フ 物ノ接続処尽ク段階习設ケサル可カラサルノ不便ナル事」 ${ }^{3)}$ と、最大 20 尺以上にも及ぶ高低差があったことが記されている。この境界部 分について江戸末期の江戸城西之丸御殿の平面図4) を見ると、ほと んどは石垣ではなく「銅垪」で区画されており、この時点では両者が それほど明確に区画されていなかったことがわかる。敷地の造成工事 については、『皇居御造営誌・工程表』（以下『工程表』）所収「第四 区負担築造期限工程進歩一覧表」に、地鎮祭直後の明治 17 年 6 月か ら 12 月にかけて「山里地違石垣」の工事が実施されたと記されてい ることから、西之丸と山里はこの石垣の設置によって初めて高低差の ある2つの敷地として明確に区画されたと考えられる。

この石垣の形状については、『皇居造営録』所收の石垣の仕様書》) に「㱭地盤上端ヨリ地山迄九尺五寸」(下線部筆者、以下同じ）と 記されており、また同史料所収の概算書 ${ }^{6}$ )に「武重石垣長延百戴拾 九間五分」と記されていることから、山里と西之丸との間に「中段」

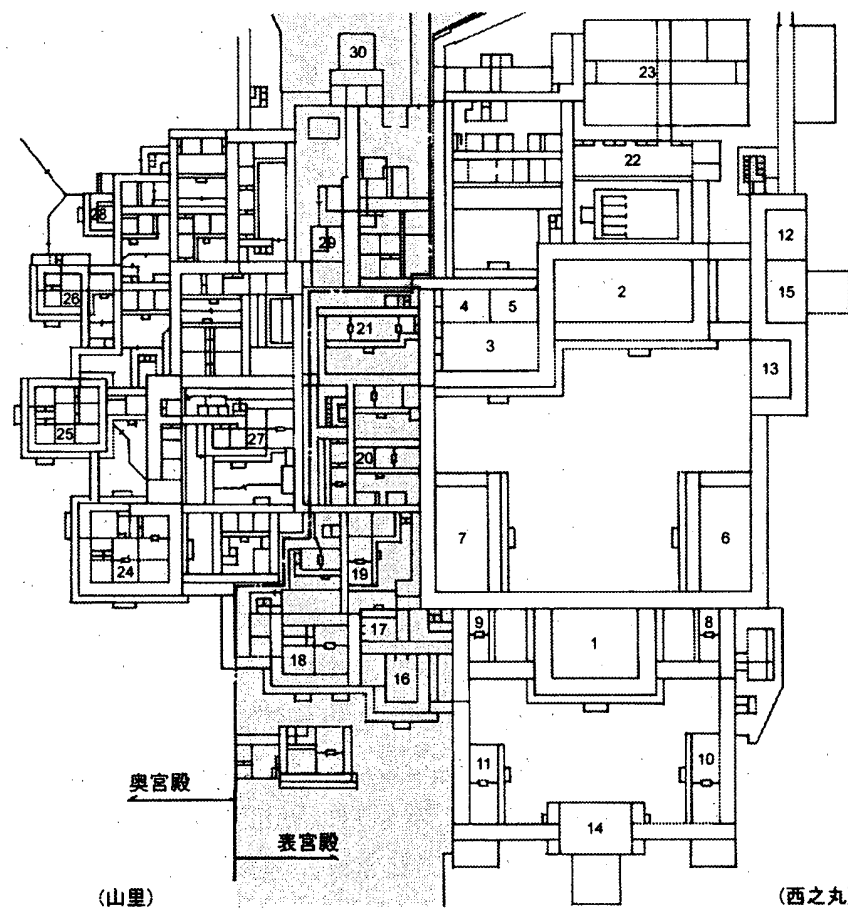

表宮殿

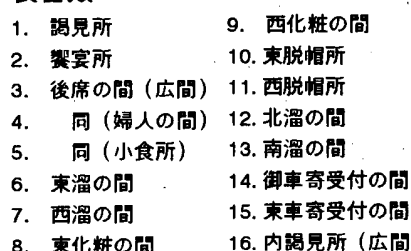
8. 束化栍の凮
奥宮殿 17. 囘 (北の间) 18. 御学问所 19. 侍従詰所 20. 佯従武官詰所 21. 皇族・大臣候所 22. 附立所 23. 大膳瞕 24. 盟上常御殿 25. 皇后宮常御殿 26. 量太后宮御休所 27. 宮御殿 28. 御雪代 29. 女官面謁斥

西之丸)

図 2. 明治宮殿竣工平面図（網掛け部分は「中段」の位置を示す）

図1、「第武区御建物床逜色分之図」(部分、明治 18 年 4 月 8 日、木子文庫所収） 
を設けた「戴重石垣」なるものであったことが知られる。この「戴重 石垣」の位置と「中段」の範囲について『皇居造営録』所収の山里の 二重石垣の配置図》を見ると、「中段」は西之丸の西側部分全体を占 めており、また石垣の高低差については、造成後の様子を示すと考え られる木子文庫所収の敷地断面図「第戴区御建物床違色分之図」(図 1） ${ }^{8)}$ に、山里と「中段」の高低差が 12 尺、「中段」と西之丸の下段 (以下「下段」) の高低差が2尺として描かれていることから、宮殿の 敷地は、この「戴重石垣」の設置によって南北方向に細長い高さの異 なる3つの領域、すなわち上段 (山里)、「中段」「下段」へと分割さ れたと考えられる。

こうした地盤の高低差を含めて作成した明治宮殿の竣工平面図9) を図 2 に示す。表宮殿の平面計画について図2を見ると、東側の「下 段」には主に 1 室大空間を持つ大規模建物が回廊に囲まれる形で建設 されたのに対し、西側の「中段」には小規模な建物が数多く建てられ たことがわかる。こうした規模の違いは建物の床高さにも直接関係す るが、建物の床高について『皇居御造営誌』を見ると、「中段」に建 設された皇族・大臣候所、侍従・侍従武官詰所などの小規模建物はい ずれも地盤から3.04尺であるのに対し、「下段」に建設された䬭宴所、 後席之間などの大規模建物については地盤から5.04尺とされており、 両者は石垣の段差 2 尺を含むことで床高がほぼ等しくなるように設定 されたと考えられる。

これら表宮殿の建物の用途については、図2に示した建設中の建物 名称がそのまま計画段階で想定された建物の主な用途を示すと考えら れるが、これによると、東側「下段」の大規模建物は、御車寄、謁見 所、饗宴所、後席之間、東西溜之間など、宮中儀礼の際に使用する建 物として計画されたことが知られ、それに対し、西側「中段」の小規 模建物は、天皇が日常的に政務を執る御学問所、天皇が臣下や外国公 使との内謁見を行う内謁見所、天皇の日常政務を補佐する侍従・侍従 武官詰所などとして計画されたことがわかる。これらのことから、表 宮殿の平面計画では、石垣の段差を利用する形で、「下段」=「宮中儀 礼の場」および「中段」=「日常政務の場」として両者がソーニング されたと見ることができる。

次に、こうした平面計画上のゾーニングを踏まえて、表宮殿におけ る室内意匠の用い方について検討した。表 1 には、入側を持つ表宮殿 の独立建物を主要建物として取り上げ、それらの室内意匠について、 『皇居御造営誌』の記載からわかるものをまとめた。表 1 では、室内 意匠を床仕上・壁面・天井の3つの部位に分類し、そのうち壁面につ いては、さらに入側建具や腰羽目などの要素に細分類した。まず、和 洋折哀として知られる表宮殿の室内意匠において和洋要素がどのよう な形で折哀されたかを見るため、表1に示した室内意匠の要素を大き く「和」と「洋」に分類した。和と洋の分類基準は、伝統的な和風建
築に用いられてきた要素を「和」とし、当時の西洋建築に用いられた 要素を「洋」とした。すなわち、暖炉については、前飾りのデザイン に関わらず設けられたものはすべて「洋」とし、床仕上げについては 畳敷きを「和」とし、䄉秋敷き・寄木張りは下地に関わらず「洋」と した。壁張付については紙張付を「和」とし、織物張付を「洋」とし た。入側建具については明障子を「和」とし、ガラス開き扉を「洋」 とした。軸組については大壁を意図的に「洋」を表現したものと見な し、縀帳と腰壁については、建物の規模に左右される可能性が高いこ とから和洋分類の主要な対象とはせず、参考として表に示した。

表 1 から、床仕上げや暖房設備など、立式の採用に伴って必要とさ れる洋風要素については表宮殿全体に導入されたことがわかる。一 方、そうした立式の導入とは直接関わらない壁張付について見ると、 「下段」の儀礼空間には洋風の織物張付が用いられたのに対し、「中 段」の御学問所・内謁見所には和風の金砂子蒔張付が用いられてお り、両者では壁仕上げの素材が区別されたことがわかる。そして、天 井意匠については、すへてに和風意匠が用いられた。

このうち、壁面と天井に用いられた和風要素の意匠的特徴について 見ると、御学問所と内謁見所の壁面に用いられた「金砂子蒋」と天井 の「(二重) 折上小組格天井」は、奥宮殿の聖上常御殿と同様の意匠 形式であったことがわかる。それに対し、儀礼空間の天井には装飾的 な漆塗りの極彩色張付天井が用いられており、両者は和風意匠の用い 方においても明確に区別されたと見ることができる。

入側建具については、「下段」の儀礼空間に洋風のガラス開き扉 (『皇居御造営誌』には「腰付硝子開」と記載) が適用されたのに対し、 「中段」の御学問所・内謁見所には、材料に「紅花櫊」(内謁見所)や 「榴」(御学問所) などの唐木 (風) 材を用い、框の入隅に丸面を取っ た中国風と考えられる意匠の引違い建 具「腰付中硝子障子」が適用された（図 3)。儀礼空間に用いられた洋風のガラ ス開き扉については、拙稿「明治宮殿の 建設経緯に見る表宮殿の設計経緯」(先 揭) で、『皇居造営録』所収の建具仕様 書の日付から、その意匠が明治 20 年 2 月〜 4月頃に洋風に決定され、また『工 事録』加ら明治 20 年 2 月〜 4 月に入側 の柱や鴨居・方立に対し、「唐戸面取」を 施すなど軸部を洋風の建具枠に見立て た変更が加えられたことを述べた （p.164）が、それに対し、例えば御学問 所の入側建具については、明治 19 年に图3.内謁見所入側建具(『皇居御 は和風の腰付ガラス障子で訫画されて

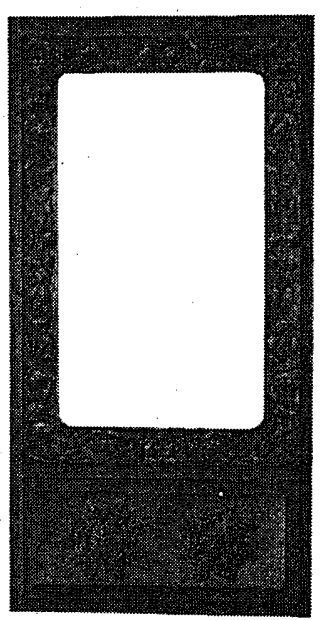
造営内部諸装飾明紐图』より)

\begin{tabular}{|c|c|c|c|c|c|c|c|c|c|c|c|}
\hline \multirow{2}{*}{ 領域 } & \multirow{2}{*}{ 建物名（室名） } & \multirow{2}{*}{ 暖妒（前飾） } & \multicolumn{2}{|c|}{ 床 } & \multicolumn{6}{|c|}{ 壁面 } & \multirow[b]{2}{*}{ 天井 } \\
\hline & & & 任上 (下地) & 維摺了 & 入剿建具 & 梁的 & 壁張付の素材 & 根饾 & 要羽眘 & 軸組 & \\
\hline \multirow{6}{*}{ 下段 } & 褁溜之䦭 & 皿気：空気暖房 & 弿木張 & 靴摫 & 漆蕉ガラス唐戸 & 無 & 悢子張 & 真 & 真 & 廻福長押（大壁） & 折上格天井漆望-極影色張付 \\
\hline & 西溜之間 & 薏気・空気暖房 & 奄木誩 & 㲎摺 & 渿湩ガラス唐户 & 無 & 悢子張 & 有 & 有 & 廻䖝長押（大垶） & 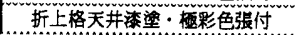 \\
\hline & 钽見所 & 蒸気.空気暖房 & 寄木張 & 靻㩇 & 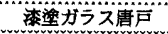 & 無 & 繲子镸 & 南 & 直 & 内法・有壁・迴粶長押 & 三重折上格天并渿酎・極影色張付 \\
\hline & 悬所 & 竟気－空気暖房 & 茼木倶 & 鞉揌 & 涷湩ガラス唐户 & 無 & 瀜子强 & 直. & 㤫 & 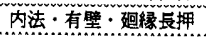 & 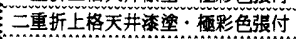 \\
\hline & 後席之間広閔 & 孚気・空気暖房 & 䈍条張 & 㲎擼 & 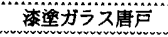 & 無 & 編子张 & 焦 & 㤫 & 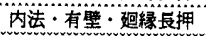 & 折上格天井渿染. 柾彩色張付 \\
\hline & 㓓之間. & 暧炉 (太理石) & 嘚木張。 & 和喟。 & (入側なし) & 無 & 悢子張 & 無 & 無 & 内法：有壁：廻緣長押 & 折上格天开渿梁-極堁色張付 \\
\hline \multirow{4}{*}{ 中段 } & 丙藏見所 & 䅼炉 (天理石) & 䨐条張 & 看搨 & 唐木ガラス障子 & 無 & 金砂子得 & 無 & 無 & 丙法：有壁－而緣長押 & 二重折上小組格天开 \\
\hline & 北間 & 暖妒 (太理石 & 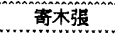 & 艄撌。 & 唐木ガラス障子 & 無 & 金㗂子請 & 䉑 & 無 & 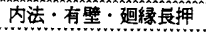 & 折上小組格天年 \\
\hline & 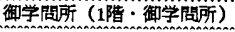 & 暖炉 (大理石) & 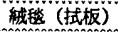 & 靴喟 & 唐木分今天陣子 & 有 & 金砂子㭙 & 無 & m & 内法-有壁－迴緣長押 & 折上小租格天开 \\
\hline & 御学問所 (2階-御学問所) & 暖炉 (大理石) & 䄉秘 $($ 拭板) & 靴摺 & 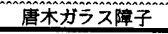 & 䈐 & 色鳥人子 & 無 & 䉑 & 内法・有壁・盂緣長押 & 䇷笴格天笑笑 \\
\hline 上段 & 脭上常御殿（御小㭫敫） & 暖炉 (蕂桧) & 䄉越 (畳) & 骨䨐 & 入子愃子 (明障子) & 有 & 金砂子蓴 & 無 & \begin{tabular}{|c|lll} 
無 \\
\end{tabular} & 内法・有壁・迴艠長押 & 二重折上小組格天井 \\
\hline
\end{tabular}


いたことが木子文庫所収の史料 ${ }^{10)}$ から知られ、実施案に見られるよ うな中国風の引違い建具への変更は、『皇居造営録』所収の仕様書「御 学問所及吳服之間共建具櫻造製作仕様書」 ${ }^{11)}$ や「内謁見所及西之間 北之間共建具花櫊造仕様書」 ${ }^{12)}$ が作成された明治 20 年 5 月〜 6 月頃 に行われたと考えられる。このように、御学問所・内謁見所への中国 風建具の導入は、儀礼空間の入側建具が洋風建具に変更された後に決 定されており、このことは「中段」の入側建具に対して意図的に洋風 意匠が適用されなかったことを示すと考えられる。

以上のように、表宮殿では平面計画のソーニングを踏襲する形で、 室内意匠の用い方が「中段」の日常政務空間と「下段」の儀礼空間と で明確に区別された。その変更の経緯と内容からは、用途の違いを室 内意匠にも反映させるとともに、特に大規模儀礼を行う儀礼空間に対 しては、壁面の洋風意匠や極彩色の張付天井など、御所の伝統にはあ まり見られない意匠を用いてでも内部空間を積極的に壮麗化しようと する姿勢を見ることができる。

\section{3 儀礼空間の平面計画に見られる近代的な儀礼形式への配慮} 前章では、表宮殿の平面計画や室内意匠が、新設された「戴重石垣」 を活用する形で「中段」の日常政務空間と「下段」の儀礼空間の $2 つ$ の領域にソーニングされ、中でも明治宮殿の特徴として知られる壮麗 な室内意匠については、儀礼空間に限って適用された意匠であったこ とを明らかにした。本章と次章では、この儀礼空間に絞ってその設計 内容を詳細に検討し、儀礼空間の平面計画には近代的な宮中儀礼への 配虑がどのような形で示されたか、またその室内意匠には「近代の宮 殿」にふさわしい意匠がどのような形で表現されたかについて考察し た。本章では、まず儀礼空間の平面計画について詳細に検討し、そこ に見られる特徵と近代的な儀礼形式との関係について論じた。

まず、敷地と建物との関係について表宮殿の配置図 ${ }^{13)}$ を見ると、南 北に細長い西之丸「下段」の敷地において、儀礼空間の建物は敷地東 側と南側に余地を残すように配置されたことがわかる。これは、坂下 門と皇居正門からのアプローチを考慮した建物配置であったと考えら れるが、このうち御車寄南側の空地については南北方向の奥行きが比 較的深く、通過動線とは別の目的で広く確保されたと考えられる。御 車寄前の空地の役割については、造営過程で「建物ノ前面八過半車馬 ノ道敷卜為サベルヨ得ス」 ${ }^{14)}$ との考え方が示されており、また竣工 後の明治 23 年の新年拝賀の際には、実際に数多くの馬車が皇居内に 駐車されたと英国公使夫人の日記 ${ }^{15)}$ に記されていることから見て、 この空地は宮中儀礼など多くの「車馬」が同時に通行する際に、車廻 しや駐車用のスペースとして活用するために設けられたと考えられ る。こうした「車馬」への配慮は、宮殿の建設と並行して行われた大 手橋 (石造橋)・二重橋 (鉄造橋) の改修工事にも見ることができ、い ずれも橋の中央部分には幅 20 尺の「車道」が確保され 16 )、また鉄橋 の強度計算においては、壹呎二付八拾封度即于四輪車二拾武瀬ノ荷 ヨ荷シタル両二耐ユルモノトス」ㄱ) と、四輪車の重量が想定された。 建物の平面計画については、儀礼空間全体を回廊で囲み、ほとんど の建物が中庭に面して配置されたことが竣工平面図から知られるが、 これは、南北に細長い敷地において外部からの視線を遮断し、かつ建 物に開放性を与えることを意図したものであったと考えられる。この うち、宮中儀礼の中心施設である謁見所と喰宴所の配置を比較する と、両者は南北方向に縦並びで設けられた2つの中庭に対してそれぞ
れ南面するように配置されており、また共通の控え室である東西溜之 間もその中間に配置されたことから、両者はほほ対等に位置づけられ たと見ることができる。しかし、両者の設計内容を詳細に検討する と、特に中庭を共有する建物との配置関係において、それそれに異な る特徴を見ることができる。

まず、謁見所の設計内容には、他の主要建物と異なる特致が多く見 られ、柱間の基準寸法には表宮殿で唯一 1 間 $=7$ 尺（他は全て 1 間 $=6.5$ 尺）が用いられた他、平面の形状には比較的正方形に近い形（室内部 分で横幅 10 間 $\times$ 奥行 8 間 =160帖）が唯一適用された。また周囲との 関係の取り方には建物単体としての独立した外観を強調する姿勢が見 られ、それは東西両隣を坪庭とし、4䇢所の渡り廊下のみで周囲と連 結した点や、その上で床高さを儀礼空間の中で最も高く設定した点 ${ }^{18)}$ などに見ることができる。そして、妻飾りの意匠には京都御所（安政 内裹）の紫宸殿と同じ「戴重虹梁蟇股枅肘木組」(他はすべて木連格 子）と「鳳凰」の破風金物（他はすべて「御紋腰折唐草」）が用いら れた。謁見所の小屋組はトラスであることから、この妻飾りの意匠は 小屋組とは無関係で、「紫宸殿との共通性」という意味において天皇 の「権威」を表現したものと考えられる。

謁見所ではこのように単体として「権威」を表現するだけでなく、 中庭を共有する御車寄や東西脱帽所との配置構成を工夫することで、 アプローチ空間からの眺めを意識した外観の「記念性」も表現された と考えられる。南正面に位直する御車寄と東西脱帽所の平面形式に は、南北軸を中心に左右相称とし、中央部の御車寄と両翼部の東西脱 帽所を前方に突き出した記念性の強い三部構成の平面形式が適用され たか、屋根については東西脱帽所が妻を正面に向けたのに対し、中央 部の受付之間では棟を東西に向けるなど、両翼に比べて中央部を強調 する姿勢がそれほど見られないことがわかる。これは、背後に控える 謁見所の大屋根への見通しを確保し、両翼に強調された東西脱帽所の 屋根と中央部に遠望される謁見所の大屋根による三部構成によって外 観の「記念性」を表現するためであったと考えられ（図4)、それは、 謁見所前庭の奥行きが 13.35 間 ${ }^{19)}$ と饗宴所前庭の 31.5 間と比べて極 めて浅いことや、謁見所の立面を真正面に眺めるための空が御車寄 「受付之間」の北壁面に設けられていない点などに覚える。

一方、喰宴所の設計内容には独自性や記念性を協調する姿勢は見ら れず、平面形式には中庭を共有する後席之間や東西溜之間とほぼ同じ 比率の横長平面を採用するなど、むしろ共通の特徴を見ることができ る。そして、これら中庭を共有する建物に見られる特徵としては、大 規模儀礼の際に必要とされる溜之間か、この中庭に面して数多く配置 された点が特に注目される。すなわち、竣工建物では東西溜之間 (各 175.5 帖) の他に、南溜之間（70帖）と北溜之間（60帖）が設けられ、 そのうち北溜之間を除く3室はいずれもこの中庭に面して配置された がこれを謁見所前の中庭と比較するとその違いは顥著で、謁見所前

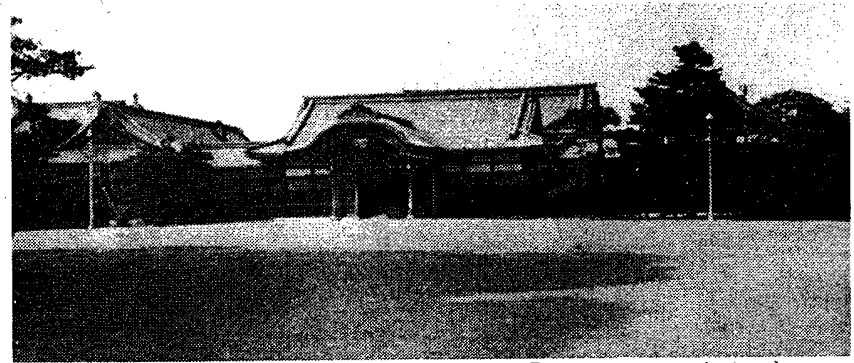

图 4. 明治宮殿御車寄外観写真（上野竹次郎編『国闘』大正 14 年より） 
の中庭に面する控室には、東西脱帽所（31帖～42帖) や化粧之間（各 15 帖）など、小規模の控室しか設けられていないことがわかる。

こうした儀礼空間の建物配置について、拙稿「明治宮殿の建設経緯 に見る表宮殿の設計経緯」(先揭)では、地鎮祭前後の明治 17 年 4 月 頃から木工事着手直前の明治 18 年 8 月にかけて、主要建物の配置に は大きな変化が見られないことを述べた（p.162）が、この間の個々 の建物の設計過程を詳細に検討すると、先に述べた謁見所や饗宴所に 見られる特徵が、この着工延期の期間に設計変更を繰り返しながら確 定して行った過程を知ることができる。例えば、謁見所の平面につい て、『皇居造営録・御車寄』所收「御車寄謁見所其外御間内模様伺之 件」附図（明治 17 年 4 月 16 日）を見ると、ここでは柱間の基準寸法 に 1 間 $=6.5$ 尺が用いられた他、平面は 8 間 $\times 8$ 間 (128帖) の正方形 平面で両隣には「謁見所東西之間」(各81帖) が計画されており、ほ ぼ同時期の木子文庫所収の床高さ比較図 ${ }^{20)}$ では、謁見所と両隣の建 物の床高が饗宴所・後席之間よりも2尺低く設定されるなど、この時 点では竣工建物のような独立性がまだそれほど強調されていなかった ことがわかる。また御車寄との関係について見ると、謁見所前の中庭 の奥行きは、宮内庁所蔵「宮殿内間取図」(明治 17 年 4 月頃、図5) $\left.{ }^{21}\right)$

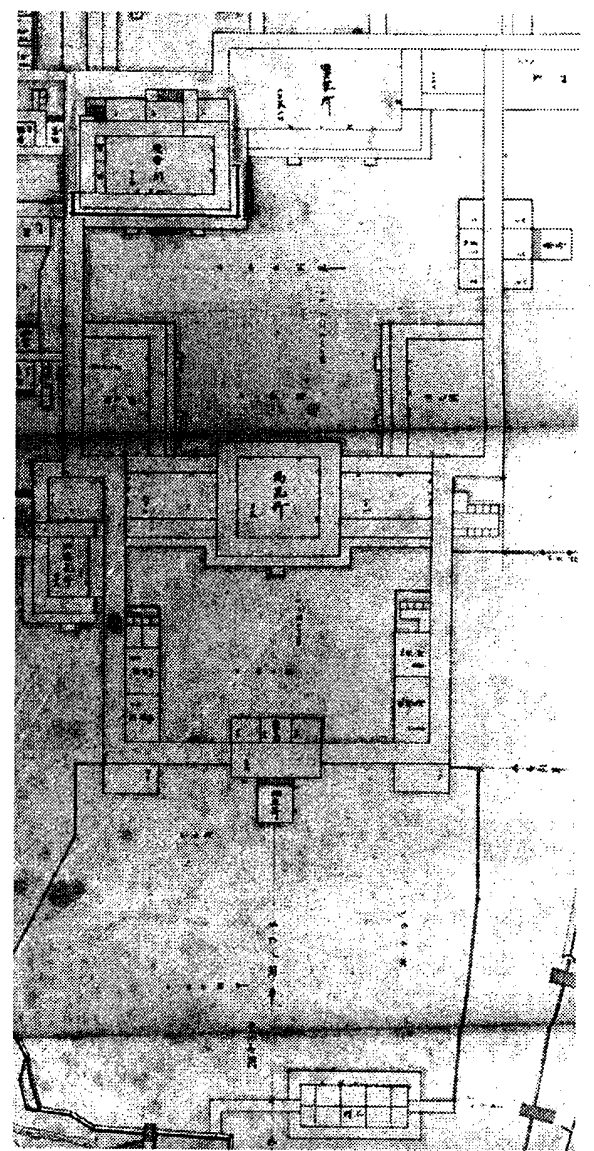

に「拾五間二分五厘」 と、実施案より広く 記されており、御車 寄受付之間の北側壁 面も明治 17 年 11 月の 木子文庫所收図面 22) には「中マ、トカラス セウシ」が計画され るなど、アプローチ 空間から望む外観の 記念性についても、 実施案ほどは強調さ れていないことがわ かる。一方、饗宴空間 の溜之間については、 当初は謁見所の周り に多く計画されてい たものが、設計変更 によって次第に篒宴 所前の中庭に移動し て行く様子を知るこ とができる。例えば、 宮内庁所藏『皇居御 因5. 宮内庁所藏「宮殿内間取图」(部分・明治 17 年 4 月頃)
などを見ると、明治 16 年 10 月頃には東西溜之間が謁見所前の中庭に 面して配置され ${ }^{23}$ 、饗宴所前の中庭には溜之間らしきものが設けられ ていないが、明治 16 年 12 月の床面積拡大後には、より広い東西溜之 間が塈宴所前の中庭に設けられたことがわかる。また明治 17 年 4 月 頃に謁見所の東西両隣に設けられていた「謁見所東西之間」は、その 後の設計変更で廃止され、実施案に至る過程では、明治 17 年 4 月頃 には計画されていなかった南北溜之間が饗宴所東側に新設された。

こうした特徴は、いずれも明治宮殿に想定された近代的な儀礼形式 に配虑したものであったと考えられる。すなわち、御車寄南側への空 地の確保は大規模儀礼の際に「車馬」が集中することを想定したもの であり、喰宴空間への溜之間の増設も同様に大規模な饗宴を想定した ものであったと見ることができる。そして、謁見所と御車寄の外観構 成によってアプローチ空間に表現された「記念性」は、近代の天皇に 求められた「権力」の視覚化 ${ }^{24)}$ を正門から参内する者に対し最も目 立つ形で表現したものであったと考えられる。宮中儀礼の中心施設で ある謁見所と饗宴所を儀礼空間の中心に据え、中庭を共有する他の建 物とも効果的に関係づけたこの平面形式は、記念性の表現や大規模儀 礼への対応といった「近代の宮殿」への要求に対し、規模に限界のあ る木造建物でも対応可能な手法として適用されたと考えられる。

\section{4. 儀礼空間の室内意匠に表現された「近代の宮殿」のイメージ}

儀礼空間の室内意匠については、表1を見る限り、洋風の壁面意匠、 華麗な装飾天井などによって、ほほ同じ仕様で統一されたと考えられ る。しかし、個々の建物に用いられた装飾モチーフや色彩については 『皇居御造営誌』の仕様書から多様であることが知られ、また『皇居 御造営内部諸装飾明細図』に収録された天井張付、建具の原色縮図や 縀帳・張付織物のサンブルからは、そうしたモチーフや色彩の違い か、宮殿の意匠表現において極めて重要な役割を担っていた様子を窥 うことができる。そこで本章では、これらの史料を用いて儀礼空間の 室内装飾について詳細に検討し、その用い方に見られる特幑とその意 匠表現の意図について考察した。

まず、儀礼空間の壁面と天井に用いられた装飾について、『皇居御 造営誌』の仕様書に記載された素材、技法、色彩、模様を表 2 にまと めた。表 2 を見ると、模様のモチーフと色彩の選び方において、謁見 所には饗宴所以下の建物と異なる特徵が見られ、壁面の模様には、 「龍」「獅子小「鳳凰」などのいわゆる「瑞鳥霊獣」モチーフが用い られ、色彩には主として張付織物・緞帳の「紫赤色」腰壁の「堆朱

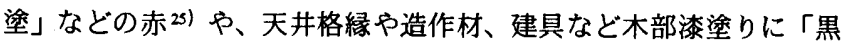
蝇色」が用いられたことがわかる。木部の漆塗りについては『工程表』 から、一旦すべての主要建物が謁見所と同様に「黒蜕色」で塗装され た (明治 20 年 1 月〜 6 月) 後、「饗宴所格天井縁紅ウルミ塗仕增」(明 治 20 年 7月 23 日〜 月 6 日）の際に、謁見所以外の主要建物がウル

表 2. 儀礼空間の室内装飾に見られる特徵 (『皇居御造営誌』およひ『皇居御造営内部諸装飾明細図』を用いて作成)

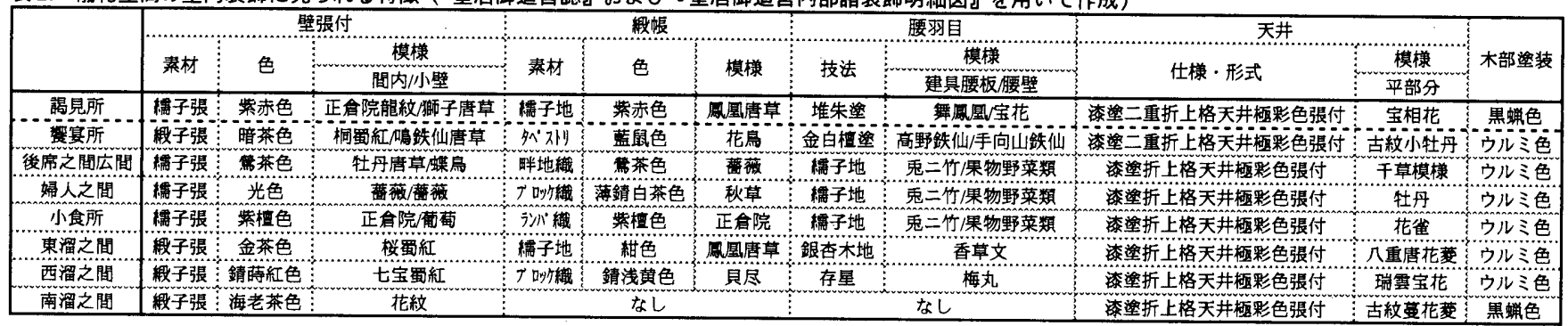


ミ色に塗り直されたことが知られ、このことにも謁見所を意図的に他 の主要建物と区別しようとする姿势が見られる。装飾モチーフに用い られた「瑞鳥霊獣」は、天皇の権威を示すために用いられたと考えら れ、また赤や黒といった色彩も、天井張付の金䈃や縀帳・玉座に多用 された金系とともに格の高さを示す色彩と考えられることから、謁見 所の室内装飾では、主に天皇の「権威」が表現されたと考えられる。

一方、饗宴所とその中庭を共有する後席之間、東西溜之間、南溜之 間については、モチーフや色彩の用い方に共通点と多様性が見られ る。モチーフの用い方について表2を見ると、これらの建物には共通 のモチーフとして「花鳥」が選択され、その中で個々の建物ことに異 なる題材が適用されたと考えられる。「花鳥」を共通のモチーフとす る姿勢は竣工後に行われた建物の改称（明治 21 年 12 月 27 日）にも 見られ、後席之間が「千種の間」(広間)、「牡丹之間」(婦人之間)、「竹 之間」(小食所）へと改称された際には、東西溜之間は「杜鵑（ほと とぎす)八間」(東溜之間)、「山鵲（かささき）八間」(西溜之間) へ、 南溜之間は「花鳥ノ間」へと改称することが検討 ${ }^{26)}$ された。また建 物ことに変化を付ける手法は色彩の用い方にも見られ、表2からは、 張付織物・緞帳の色彩も建物ことに変えられたことが知られ、また木 部の塗装に用いられたウルミ色についても、『皇居御造営内部諸装飾 明細図』所收の建具の縮小絵図を見る限り、ウルミ色の明るさや色の 調子が建物ことに変えられていた様子が窺える。このように、塈宴所

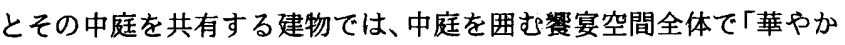
さ」を醸し出すように室内装飾が用いられたと考えられる。

篒宴空間全体で華やかさ」を演出しようとする姿勢は、饗宴所前 の中庭の扱いにも見ることができる。中庭の竣工時の様子について 『皇居御造営誌・御庭作事業』所収「豊明殿前御庭作繪図」(図 6) を 見ると、中央には「古銅水盤」27)を用いた噴水が据えられ、饗宴所、 後席之間、東西溜之間から中央の噴水へは、それそれに苑路が設けら れた他、『皇居造営録』所収「饗宴所中庭御庭作入費之件伺」28)から、 樹種には花の咲く木 (ツッジ、サクラ、ウメ、サルスベリ、モクレン、 モクセイ) や紅葉する木 (サクラ、カエデ) など、四季の変化を楽し めるものが多く植えられていたことが知られる。このように、飧宴空 間の中庭は建物内部からの眺望とともに、散策することも想定して設 計されており、視覚的にも実際の利用形態においてもこの中庭にはこ

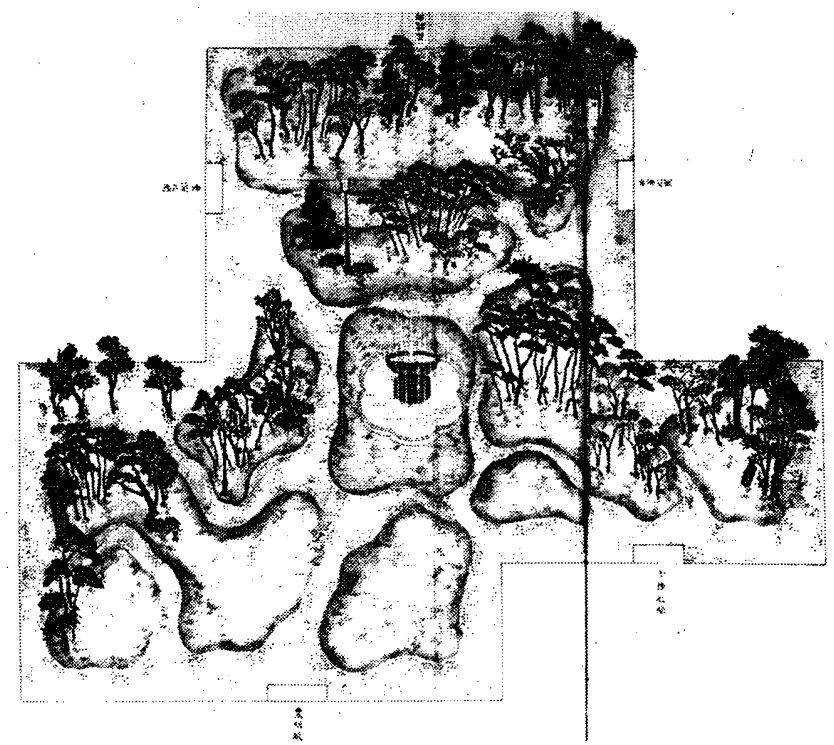

図 6.「豊明殿前御庭作繪図」(『皇居御造営誌·御庭作事業』所収、宮内庁所蔵)
れらの建物を結びつける役割が期待されたと考えられる。

以上のように、儀礼空間の室内意匠では装飾モチーフと色彩を使い 分けることで謁見所には「権威」が、饗宴所とその中庭を共有する建 物には「華やかさ」が表現されたが、謁見所に独立性を与え、䲗宴所 を中庭を共有する建物と一体的に扱う手法は、前章で見た平面計画と 共通のものであることから、こうした儀礼空間の室内意匠は、平面計 画の設計意図を踏襲する形で天皇の「権威」や大規模な銥宴にふさわ しい華やかなイメージを表現したものであったと見ることができる。

儀礼空間の室内装飾に見られる特致としては、こうしたモチーフゃ 色彩の用い方の他に、ほぼすべての装飾が「文様」によってデザイン された点も挙げられる。『皇居御造営誌』にはこれら室内装飾に用い られた文様について注記が書き添えられており、例えば謁見所の天井 模様 (二重平)については、「意匠東大寺経函繪紋」と記されている。 古代宝物が装飾模様の参考にされたことについては、『明治工業史 建築篇』第五編第一章第一節「宮城表宮殿の装飾」で詳しく紹介され ており、また多くの先行研究でも触れられてきたが、ここでは引用元 の宝物を特定するとともに、それらがどのような経緯を経て引用され たかにも注目することで、そのデザインの意図について考察した。

まず、『皇居御造営誌』記載の注記と『皇居御造営内部諸装飾明細 図』に収録された縮小絵図・サンプルを手掛かりに、これら装飾模様 の引用元を調べたところ、少なくとも図 7〜 10に示した 4 件につい ては、表3に示した引用元と考えられる正倉院宝物や平家納経などの 宝物文様と極めて良く似たデザインであることが確認できた。このこ
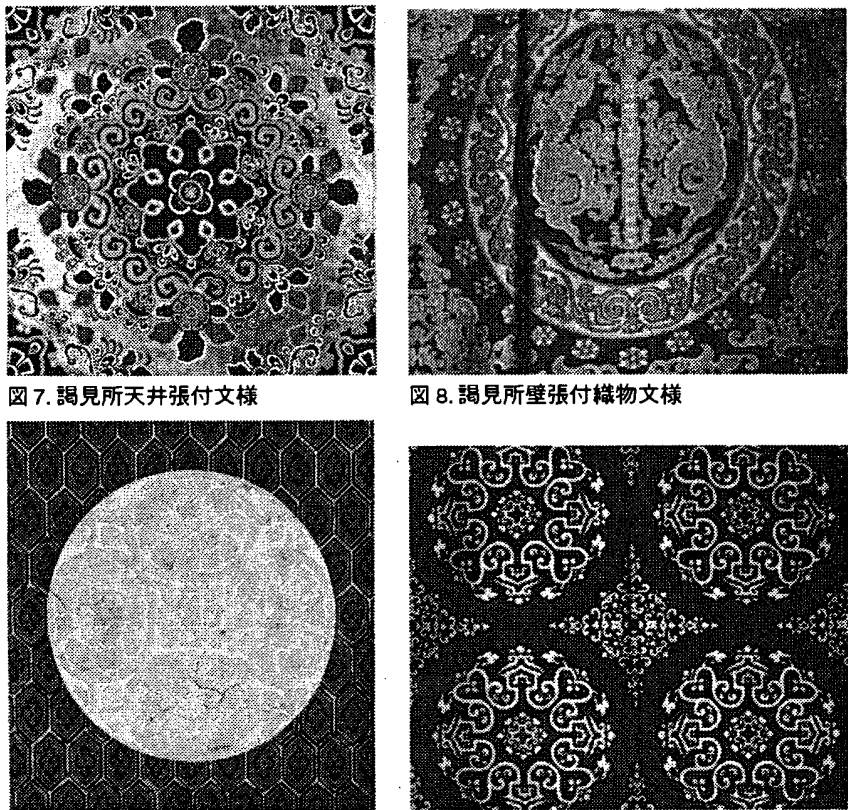

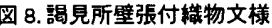

图 9. 絜宴所天井張付文梯

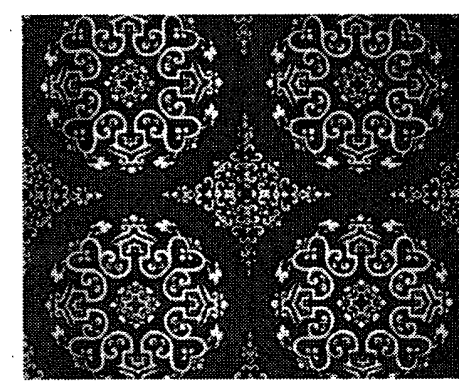

图 10. 東西脱帽所ほか壁張付織物文様

图 7-10. 樣礼空問の装飾文様（『皇居御造営内部諸装飾明細図』所収）

表 3. 儀礼空間の㯏飾文様とその引用元と考えられる宝物

\begin{tabular}{|c|c|c|c|}
\hline & 建物（部位） & 注記『皇居御造営誌』 & 引用元と考えられる宝物 \\
\hline \multirow{2}{*}{ 図7 } & 謁見所・天井 & \multirow{2}{*}{ 「東大寺経目絵紋」 } & 正倉院宝物 \\
\hline & (二重平) & & 「密陀彩絵箱」 \\
\hline \multirow{2}{*}{ 図8 } & 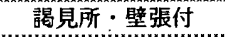 & \multirow{2}{*}{ 「正倉院龍紋」 } & 正倉院宝物 \\
\hline & (間内) & & 「双龍唐草円紋緑綾」 \\
\hline \multirow{4}{*}{ 荬 } & 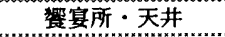 & \multirow{2}{*}{ 「政子手函浮線緽紋」 } & サル-美術館所蔵 \\
\hline & (二重平・田紋) & & 「浮線綾蟔鈿荨絵手箱」 \\
\hline & 㕠县所・天井 & \multirow{2}{*}{ なし } & 平家納経「人記品」表紙 \\
\hline & (二重平.地紋 $)$ & & 「重甲花蓔紋」 \\
\hline \multirow{2}{*}{ 四10 } & 東西脱帽所他·壁張付 & \multirow{2}{*}{ 「宝花」 } & II 倉院富物 \\
\hline & (間内) & & 「䇣地篬花文鎙」 \\
\hline
\end{tabular}


とは、これら文様のデザインに際して、実物か実物に関する詳しい史 料が何らかの形で参照されたことを示すと考えられるが、皇居造営 録・日誌』に、「㛜島神社蔵経模本八巻豫而山高博物館長心得承知二

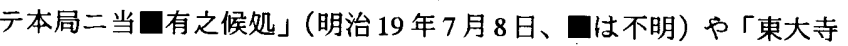
所傳古裂写一冊昨十八年五月以来杉局長図書寮以借用之処」(明治 19 年 12 月 2 日）などの記述が見られることから、これら宝物文様の引 用に際しては、博物館所蔵の平家納経の模写本や宮内省図書寮所蔵の 正倉院宝物の模写本などが参照された可能性が高いと見られる。

儀礼空間の室内装飾に正倉院宝物など古代宝物の文様を引用した理 由について、『皇居御造営誌・絵画』には「古今内外文質雅致透逸ノ 参照 7 廣遠二求入参考書籍画譜古錦紼名勝地ノ巨刹寺院ノ遺蹟二存在 セル画趣ノ妙味习交照二取り各専門家ノ匠意 $モ$ 容採シ官私所蔵什器 ヨ借用スル」と記されており、少なくとも威圧的なものよりは雅やか なモチーフを好んで選択した様子が窥える。なお、近世書院造の遺構 において、正倉院宝物や平家納経など著名な古代宝物の文様をそのま ま格天井の文様に使用した事例は知られていない29)ことから、こう した宝物文様を直接的に引用する装飾手法は、近代的な伝統表現の手 法として新たに創出されたものであったと考えられる。

ところで、『皇居造営録』には明治 17 年以降に御造営事務局が蒐集 した絵画資料の記録が残されており、伝統表現の方法がさまさまに検 討された様子を知ることができる。これを見ると、明治17年には「旧 本丸張付絵様式百武拾四巻」30)や「京都御所安政度御造営間内御襖 張付等之絵様雊形」31) など主に障壁画の下絵が蒐集されたのに対し、 明治 19 年には「丹鶴図譜」や「集古十種」など伝統的な宝物の模写 本が数多く蒐集され ${ }^{32}$ 、また日光東照宮の文様調查 ${ }^{33)}$ も実施される など、意匠的な関心が文様へと変化した様子が窅える。『皇居御造営 誌』には、「総テ繪画或八彩色等二係ル事八博物館長山高信離専ラ之 ᄏ指揮セリ」 ${ }^{34)}$ や其花紋ノ意匠八博物館長山高信離ノ考案二出」 $\left.{ }^{35}\right)$ と、装飾文様が明治 18 年 6 月 8 日に啒託として宮殿の造営に参加し た山高信離によってデザインされたと記されていることから、蒐集資 料の内容の変化も山高の意向であった可能性が高い。また山高信離 は、明治 10 年代を通じて農商務省博物局で各種の宝物調查や伝統工 芸品の改良事業に関与していたことが知られているが36)、こうした宝 物文様の引用には、山高が明治 10 年代の美術行政を通じて培った伝 統美術に関する見識や人脈が反映していることも考えられる ${ }^{377 。}$

\section{5. 装飾品の生産に活用された近代技術}

前章では、儀礼空間の室内意匠において、建物ことに色彩やデザイ ンに変化が付けられ、またその模様には古代宝物の文様が精緻に引用 されていたことを述べたが、こうした手法を実践するには、大空間の 壁や天井を唯い尽くす大量な装飾品を、竣工に間に合うように短期間 で生産できる技術的な裏付けが不可欠であったと考えられる。本章で は、これら儀礼空間の室内意匠に用いられた装飾品の生産過程につい て检討を加え、その生産体制には明治 20 年頃の日本における最新の 技術が積極的に活用されていたことを述べる。

まず、天井張付の模様紙については、『皇居御造営誌』に「各宮殿 折上天井格間略込装飾二用ユル大鷹質華紋打出紙及七各所廊下ノ壁張 二要スル花紋紙等ノ製作方 $ᄏ$ 印刷局二嘱托ス」 ${ }^{38)}$ とあり、『印刷局沿 革録』 ${ }^{39)} に も 「$ 是年（筆者註・明治 19 年）皇居御造営用壁紙 7 製造 ス」とあることから、模様紙は大蔵省印刷局の「打出」印刷によって
製作されたと見てほほ間違いない。当時の印刷局では、ドイッから購 入した壁紙製造機を用いて輸出品の金唐革紙を盛んに製造していたこ とが知られており 40 、この模様紙の「打出」印刷にも金唐革紙の製作 技術が活用された可能性が高いと見られる41)。一方、模様紙の彩色に ついては、『皇居御造営誌・絵画』所収「格天井打出模様紙彩色」に、 東西脱帽所を除くほとんどの建物の彩色を「小池有終」なる人物が請 け負ったことが記されているが、この人物については、『皇居造営録』 所収「御請書」42）から「精工社」の代理人であったことが確認でき る。「精工社」については、明治初期に美術工芸品の製作・改良・技 術伝習などに活羅した民間の勧工場附属工場であったことが知られて

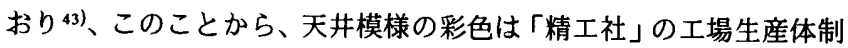
を利用して大量に製作された可能性が高いと考えられる。

錺金物のメッキについては、『皇居御造営誌』の記録から、奥宮殿 の建物や御学問所には水銀鍍金や「墨指」など伝統的な技法が用いら れたのに対し、儀礼空間の建物には「電気鍍金」が用いられたことが わかる。錺金物の電気鍍金がどこで施されたかは不明であるが、電気 鍍金が一般に普及したのは明治 27 年の日清戦争以降とされている44) ことから、明治宮殿の事例は極めて初期のものと考えて良い。

壁張付や緞帳に使用された織物については、皇居御造営誌・家具 事業』の「欧州製二模擬シタル錦紼綾羅习織ラシム」との記述から、 洋風の織り方が取り入れられたことが知られ、また『皇居御造営誌・ 織物事業』には、「仏國製ジャカール製メカニク三百本ノロヨ用ユ」 と、文様織物に強いジャカール織機を使用したことが記されている。 ジャカール織機による文様織りは系の先染めを必要とするが、この織 系の染色については『皇居御造営誌・織物事業』所収の仕様書に、「赤 アリジヤリン染」や「黒ログウード染」と記されていることから、当 時フランスで開発されて間もない合成染料（アリザリン染め、ログ ウッド染め)が使用されたと考えられる。合成染料を採用した意図に ついては、皇居御造営事務局が織物担当の荒川新一郎に電報45)で「日 本染ハ色変ル如何計ラウテ能キ力」（明治 20 年 6 月 27 日）と、伝統 的な染色技術に対する不安を示しており、おそらく洋風の壁張付織物 や縀帳に求められた華麗な色彩、発色の明快さ、色彩の多様性、色裉 せの防止などを期待して合成染料を採用したものと考えられる。そし て、「色染八彼是手 ヨ尽シ稲畑ノ法二依り殆ド望通二染儿積り」(明治 20 年 6 月 29 日）との電報があることから、染色の技術指導は、リヨ ンへの留学経験を持ち、当時京都府織殿御用掛で染色技術の近代化に 努めていた稲烟勝太郎 ${ }^{46)}$ によって行われたと考えられる。

以上のように、儀礼空間の装飾には近代的な生産体制が積極的に活 用された。儀礼空間の建物に見られる大空間には、トラスや煉瓦基礎 などの洋風技術が適用されたことが知られているが、そうした構造技 術ととともに、壮麗な室内装飾もまた当時の日本の最新技術を用いて 初めて可能になったものであったといえる。すなわち、儀礼空間の壮 麗な室内意匠は、デザインと生産技術の両面において近代化を積極的 に取り入れた、新しい形の意匠表現であったと見ることができる。

\section{6. 結論}

本稿では、宮内庁所蔵史料や木子文庫所蔵史料を用いて、明治宮殿 の表宮殿に見られる意匠的特徴を平面計画と併せて検討し、その特徴 が近代の宮殿」に対する要求とどのように関係づけられたかに注目 して考察することで、以下のことを明らかにした。 
明治宮殿の建設された西之丸・山里の敷地は高低差が最大で 20 尺 以上もあったが、造営過程では「戴重石垣」が新設され、敷地は高さ の異なる3つの領域に区画された。西之丸はこれにより「中段」と「下 段」に分割され、平面計画ではこの高低差を利用する形で「中段」= 日常政務の場、「下段」=宮中儀礼の場という形にソーニングされた。 表宮殿ではこの平面計画のソーニングを踏襲するように室内意匠が用 いられたと考えられ、和風色の強い「中段」に対して「下段」の儀礼 空間に限っては壁面の洋風意匠や壮麗な天井意匠が適用された。

儀礼空間の平面計画を詳細に検討すると、宮中儀礼の中心施設であ る謁見所と饗宴所では、中庭を共有する建物との配置関係に異なる特 徵が見られた。謁見所は単体で「権威」を表現しつつ、謁見所の大屋 根と正面の左右相称の東西脱帽所の屋根による三部構成によって御車 寄前のアプローチ空間に「記念性」を表現したのに対し、饗宴所前の 中庭には、大規模儀礼の際に必要とされる溜之間が集中的に配置され た。これは、それそれ「近代の宮殿」に要求された「権威」の表現や 大規模な儀礼に木造建物に可能な手法で対応したものと考えられる。 儀礼空間の室内意匠では、室内装飾の色彩と装飾モチーフの用い方 において、平面計画と同様に謁見所には独立性が与えられ、錅宴所以 下の建物は一体として扱われた。すなわち、謁見所では瑞鳥霊獣のモ チーフと赤・黒などの色彩によって「権威」が表現され、饗宴所と中 庭を共有する建物では花鳥モチーフとその中での多様な意匠や色彩、 そして中庭によって「華やかさ」が表現された。

室内装飾に用いられた文様には、博物館所蔵の正倉院宝物や平家納 経などの古代宝物文様の模写本などが参照され、ほぼ正確に引用され たと考えられる。宝物文様の引用は、威圧的なものよりも雅やかな意 匠が好んで選択されたが、こうした手法は、近世には見られない近代 的な伝統表現の手法として適用されたと考えられる。模様のデザイン には山高信離が中心的役割を果たしたが、そこでは山高が明治 10 年 代の美術行政で培った見識・経験・人脈が活用されたと考えられる。

これら装飾品の生産体制には、大藏省の印刷技術、「精工社」、電気 鍍金、ジャカール織機、合成染料など、当時の日本の最新技術が積極 的に活用された。このように、儀礼空間の壮麗な室内意匠は、「近代 の宮殿」に対する複雑な要求に配虑し、かつ「近代化」を積極的に取 り入れて創出された、新しい形の意匠表現であったと考えられる。

[謝辞］本稿を作成するに当り、宮内庁書陵部（当時）の小坂敏郎氏 には史料閲覧に関してお世話になりました。記して謝意を表します。 [註]

1）明治宮殿を扱った通史としては、桐敷真次郎『明治の建築』（日経新書、昭 和 41 年、pp.95-98)、村松貞次郎・近江栄編『近代和風建築』（鹿島出版会、 昭和 63年、pp.114-117) がある。表宮殿の内部装飾に関する個別研究として は、桐敷真次郎「宮殿建築の『種』一明治宮殿の室内装飾と二代川島甚兵衛 一」(『KAWASHIMA』12号、昭和 58 年 9 月) がある。

2) 同書では、内部意匠について「奥宮殿の諸殿舎は、書院造の性格の強い、か つ和風を主体とする建物であった。これに対して、表宮殿の諸殿舎は、紫宸 殿なども参考にされ、外観をはじめ、主体部は和風を継承するものであった が、外交上洋式儀礼を導入しなければならなかった時代の特性を反映して、 建築とくにその構造面や内部装飾において洋式か顕著に導入されていること がわかるj(p.18) とある。

3)『皇居衙造営誌・巻之四』明治 14 年 11 月 24 日条

4）江戸城西ノ丸の図面には、元治度「江戸城西丸仮御殿総地絵図」(『城郭·侍 屋敷古図集成・江戸城 $1<$ 城郭>』至文堂、平成 4 年、pp.76-77) を用いた。

5）『皇居造営録・石垣（山里）』所収「山里御敷地々違イ石垣地形根切堀割ヨ リ該土引均方仕様畫」(明治 17 年 4 月)

6)『皇居造営録・石垣（山里）』所収「山里御敷地々違戴重石垣築造入費概算 積書」(明治 17 年 4 月)

7)『皇居造営録・石垣（山里）』第 1 巻所収、山里石垣配置図（無題）

8）木子文庫所収「第牙区御建物床違色分之図」(休高さ比較図、史料番号 · 木 111-3-007: 明治 18 年 4 月 8 日)、石垣の造成は明治 17 年末に終了してお
り、この図が最終的な状態を示していると考えられる。

9)『皇居御造営誌編算下調図』所收「謁見所以下地之間図」(表宮殿、日付な し）「常御殿以下四百分一」（奥宮殿、明治 18 年 8 月調）を用いて作成した。 これらは内容から最終図面と考えられ、竣工時に最も近いと考えられる。

10) 木子文庫所収・御学問所建具図（木092-4-010、明治 19 年 2 月 28 日）

11) 『皇居造営録・御学問所』所収、明治 20 年 5 月

12）『皇居造営録・内謁見所』所収、明治 20 年 6 月

13）『建築雑誌』第 25 号「宮城地繪図」附図参照、明治 22 年 1 月

14）『皇居御造営誌・巻之四』明治 14 年 11 月 24 日条（山里正殿に関する記述）

15）メアリー・フレイザー著・横山俊夫訳『英国公使夫人の見た明治日本』(淡 交社、昭和 63 年) には、明治 23 年の新年拝賀について「皇居の車寄に達す るには長いまわり道をしなければなりません。そして内庭にはすでに数多く の馬車が到着していましたので、私たちは遅れたのではないかと心配になる ほどでした」(p.136) と記されている。

16）『皇居御造営誌・石橋架設事業』所収「大手石橋新築仕様書」に「車道巾 縁石内武拾尺」とあり、同様に『皇居御造営誌・鉄橋架設事業』所収「鉄橋 架設仕様書」に「車道柣寄セ木張巾武拾尺」と記されている（附図あり）。

17)『皇居御造営誌・鉄橋架設事業』所收「二重橋構造明細書翻訳」(明治 19 年 10月2日）

18）図 1 (註 8 参照) より、儀礼空間の床高は謁見所を基準に、裟宴所と後席 之間は 0.76 尺、東西溜之間は 1.5 尺、御車寄受付之間 2.14 尺それそれ低い。 また庭に面した階段の段数は、謁見所が 8 段、襄宴所・後席之間が 7 段、東 西溜之間が 6 段となっている。

19）『皇居御造営誌』記載の柱間寸法から算出した（1 間 =6.5尺換算）。

20）木子文庫所収・床高さ比較図（木 109-1-018、明治 17 年 2 月 21 日）

21）宮内庁書陵部所蔵、日付はないが『皇居衙造営誌編策下調図』第 88 号図 面（明治 17年7月 14 日）と平面がほほ一致することから判断した。

22）木子文庫所収・御車寄平面図（木102-1-066、明治 18 年 1 月 14 日）

23）掲見所前庭の東西に位置する建物 (実施案の東西脱帽所の位置)について、 木子文庫所収「第戴区御建物家根種分図」(木123-1-031、明治 16年 10月頃) には「溜之間」と記入されている。

24）明治初期の「天皇の視賞化」をめぐる一連の動きについては、多木浩二『天 皇の肖像』(岩波新書、昭和 63 年) に詳しい。

25）謁見所の玉座天蓋にも「赤天䄉」の裂地が用いられている。(『皇居御造 営誌・家具事業』所収「家具及敷物約定書附属書」より)

26）『恒例儀式録』所収「孝明天皇御例祭二付舎人配役」（明治 22 年 1 月 30 日） には、東溜之間が㩯ノ間」西溜之間が「紅葉ノ間」南溜之間が「柳ノ間」 北溜之間か「桃ノ間」と記されている。

27）『皇居造営録・庭園』所収「装宴所中庭へ古銅水盤据付台石水管并二泉水 仕拵仕様」(明治 20 年6月14日）に「右八延遼館庭前二据付有之処取崩シ筡 宴所中庭迄不損様四生運送致シ」とあることから、噴水頂部の古銅水盤は芝 の延遼館から移設したものと考えられる。

28）皇居造営䟿・庭園』所収「溊宴所中庭御庭作入費之件伺」(明治 20 年 5 月 26 日)、中島卯三郎『皇城』（雄山閣、昭和 34 年）p.160の記述も同じ。

29）宮城学院女子大学学芸部教授・後藤久太郎博士の御教示による。

30)『皇居造営録・絵画』所収、明治 17 年 10 月 20 日

31）『皇居造営録・絵画』所收、明治 17 年 6 月 10 日

32）『皇居造営録・雑品』所収「花鳥図式其他買入方之義何」(明治 19 年 8 月 29 日）および「図書購買方伺」（明治 19 年 12 月 28 日）他多数

33）『皇居御造営誌・巻之七』明治 19 年 7 月 11 日条、『皇居造営録・絵画』に は「右者日光山社寺建物之紋様参考入為着色模写致之置度」(下線部筆者、明 治 19 年 8 月 22 日) とある。

34) 『皇居御造営誌・家具事業』第 1 巻

35）『皇居御造営誌・巻之七』明治 20 年 2 月 9 日条

36) 山高信離（1840～1907）の経歴については、關千代「皇居杉戸絵につい て」(『明治宮殿の杉戸絵』博物館明治村、平成 3 年) などを参考にした。

37）例えば、平家納経の模写事業については小松茂美『平家納経の研究（下）』 （講談社、昭和 51 年）に詳しく、これによると模写は山高信離の指導の下に 明治 16 年 5 月〜 17 年 5 月に農商務省博物局で行われ、面工には長命曼春、前 田貫業、(遠藤) 貫周なと、後に皇居造営に関わる者が多く携わっている。

38）『皇居御造営誌・巻之八』明治 20 年 2 月 9 日条

39）『印刷局治革録』（印刷局、明治 40 年）p.126、「お札と切手の博物館」所蔵 40) 久米康生「明治の “芸術産業” 金唐革紙」(『きんからかわ・革と紙の東西 交流』INA BOOKLET、昭和 55 年)、P.57

41）「お札と切手の博物館」には、明治宮殿の壁紙として伝わる金唐革紙製の 壁紙が保存されている。

42）『皇居造営録・絵画』所収、「御請書」(明治 20 年 4 月 27 日)

43)『明治デザインの誔生一調查研究報告書『温知図録』一』(東京国立博物館 編、平成 9 年) によれば、精工社は明治 11 年に設立され、明治 20 年には男 子工貝 350 名を抱えている。(同書「人名注解」p.51より要約)

44）『東京都鍍金工業組合八十年史』(東京都鍍金工業組合、昭和 46 年)に、「明 治 20 年ころから宮川電鍄が電気メッキ法を採用して企業を起し（中略）電 気メッキの工場生産体制が整って、探算ベースに乗ってきたのは 27 年前後 の日清戦争による、メッキされた金属加工品が大量に受注されるようになつ てきてからであろう」(p.35) と記されている。

45）『皇居造営録・雑品』第 41 巻所収

46) 稲畑勝太郎 $(1862 \sim 1949)$ は、明治 19 年 7 月 20 日に「皇居御造営装飾用 織物染色取調」を依嘱されている。(『皇居造営録・雑品』第 22 巻所収) 